\title{
PELATIHAN PEMBUATAN HAND SANITIZER BERSTANDAR WHO \\ BAGI KELOMPOK IBU PENERIMA PKH DI DESA JARISARI KECAMATAN JENGGAWAH
}

\author{
Alifian Nugraha \\ Progam Studi Ilmu Administrasi Niaga \\ Sekolah Tinggi Ilmu Administrasi Pembangunan Jember \\ *Email: iandgrahasaputra@gmail.com
}

\begin{abstract}
ABSTRAK
Kesehatan merupakan aspek yang sangat penting bagi kehidupan. Memelihara kebersihan tangan sebagai salah satu upaya dalam menjaga kesehatan tubuh. Masyarakat tidak sadar bahwa dalam beraktivitas, tangan seringkali terkontaminasi dengan bakteri. Bakteri berpotensi menjadi patogen jika jumlahnya melebihi batas dan akan menjadi bahaya bagi manusia. Salah satu cara paling mudah dalam menghambat penyebaran bakteri yaitu dengan mencuci tangan. Mencuci tangan dapat menurunkan jumlah bakteri sampai dengan 58\%. Masyarakat sering menggunakan gel antiseptik sebagai media pencuci tangan (Hand sanitizer) untuk menggantikan sabun dan air agar lebih praktis. Pemakaiannya yang efektif dan efisien menjadi daya tarik utama dari Hand Sanitizer. Progam pelaksanaan pelatihan pembuatan hand sanitizer berstandar WHO (World Health Organization) diberikan kepada masyarakat Desa Jatisari, Kecamatan Jenggawah, Kabupaten Jember. Dikhususkan kepada kelompok sasaran yaitu kelompok ibu penerima PKH. Pada progam pelatihan ini memiliki target capaian yaitu memberikan pengetahuan dan keterampilan untuk masyarakat sasaran agar bisa membuat hand sanitizer secara mandiri untuk mengantisipasi pencegahan penyebaran Covid-19. Kata Kunci: Pelatihan, Hand Sanitizer, Covid-19
\end{abstract}




\section{Analisis Situasi}

Kesehatan merupakan aspek penting yang dapat mempengaruhi quality of life setiap individu. Salah satu cara yang efektif untuk menjaga kesehatan tubuh adalah menjaga kebersihan, salah satunya adalah kebersihan tangan (Radji, 2010) karena tangan adalah salah satu anggota tubuh yang sangat berperan penting dalam beraktivitas seharihari. Masyarakat tidak sadar bahwa pada saat beraktivitas tangan sering kali terkontaminasi dengan mikroorganisme karena tangan menjadi perantara masuknya mikroba ke saluran cerna.

Mencuci tangan merupakan langkah awal untuk menghindari berbagai jenis kuman penyebab penyakit infeksi tetapi langkah ini sering kali diabaikan ataupun terlewatkan begitu saja. Seiring dengan perkembangan zaman kesadaran manusia untuk selalu menjaga kesehatan pun meningkat, kesehatan merupakan aspek yang penting bagi kehidupan. Dalam menjaga kesehatan, memelihara kebersihan tangan merupakan aspek penting, karena seluruh aktivitas sehari-hari yang dilakukan berawal dari tangan itu sendiri sehingga tangan dapat menjadi perantara masuknya mikroba ke dalam tubuh.

Mencuci tangan merupakan teknik dasar yang paling pentingdalam pencegahan dan pengontrolan infeksi (Potter \& Perry, 2005).Mencuci tangan merupakan proses pembuangan kotoran dan debu secara mekanis dari kedua belah tangan dengan memakai sabun dan air. Tujuan cuci tangan adalah untuk menghilangkan kotoran dan debu secara mekanis dari permukaan kulit dan mengurangi jumlah mikroorganisme (Tietjen, 2003 dalam Moestika). Diare biasanya kuman ditransmisikan dari tangan yang tidak bersih ke makanan. Kuman-kuman kemudian memapar ke person yang makanan tersebut.

Dampak yang terjadi tidak mencuci tangan dengan sabun adalah penyebaran penyakit menular seperti diare, infeksi saluran pernafasan atas (ISPA) dan flu burung, bahkan disarankan untuk mencegah penularan influenza. Pada umumnya, orang sudah melakukan cuci tangan 
setiap hari, akan tetapi belum melakukan cuci tangan yang benar, dalam artian cara melakukan cuci tangan maupun kapan harus cuci tangan belum maksimal.Padahal perilaku cuci tangan yang benar dan dilakukan sehari-hari mempunyai dampak positif yang besar terutama dalam 3 pencegahan penyakit. Kebiasaan tidak cuci (sebelum menyiap kan makanan, sebelum makan, setelah buang air besar, setelah dari sawah/kebun/setelah anakanak bermain dengan tanah) dan atau cuci tangan yang tidak benar (cuci tangan dengan air dalam kobokan yang biasanya dipakai beramai ramai, cuci tangan saja tanpa memakai sabun), ternyata dapat menyebabkan penularan penyakit, terutama penyakit yang ditularkan melalui air dan lingkungan.

Hal ini bisa diegah dengan selalu mencuci tangan setelah menggunakan toilet dan sebelum menyiapkan makanan (Darmiatun, 2013). Mencuci tangan juga dapat menghilangkan sejumlah besar virus yang menjadi penyebab berbagai penyakit, terutama penyakit yang menyerang saluran cerna, seperti diare dan saluran nafas seperti influenza. Hampir semua orang mengerti pentingnya mencuci tangan pakai sabun, namun masih banyak yang tidak membiasakan diri untuk melakukandengan benar pada saat yang penting (Umar, 2009 dalam Mirzal).

Tangan merupakan bagian tubuh yang lembab yang paling sering berkontak dengan kuman yang menyebabkan penyakit dan menyebarnya. Cara terbaik untuk mencegahnya adalah dengan membiasakan mencuci tangan dengan memakai sabun (Kamarudin, 2009 dalam Mirzal). Mencuci tangan adalah teknik yang sangat mendasar dalam mencegahdan mengendalikan infeksi, dengan mencuci tangan dapat menghilangkan sebagian besar mikroorganisme yang ada di kulit. Sebagian masyarakat mengetahui akan pentingya mencuci tangan, namun dalam kenyataanya masih sangat sedikit (hanya 5\% yang tahubagaimana cara melakukanya dengan benar. Hal ini sangat pentinguntuk di ajarkan pada 
masyarakat agar bias mencegah terjadinya penyakit ( Siswanto, 2009 dalam Zuraidah ).

Mencuci tangan memakai sabun sangat penting sebagai salah satu mencegah terjadinya diare, kebiasaan mePerilaku sehat cuci tangan pakai sabun yang merupakan salah satu Perilaku Hidup Bersih Sehat (PHBS), saat ini telah menjadi perhatian dunia, hal ini karena masalah kurangnya praktek perilaku cuci tangan tidak hanya terjadi di Negara berkembang saja, tetapi ternyata di Negara maju pun kebanyakan masyarakatnya masih lupa untuk melakukan perilaku cuci tangan (Depkes, 2007). Perilaku hygiene seperti mencuci tangan dengan menggunakan sabun dan air bersih yang tepat sebagai cara yang efektif untuk mencegah penyebaran berbagai penyakit menular seperti penyakit diare dan ispa. Namun pada kenyataannya, penerapan perilaku mencuci tangan dengan sabun dan air bersih yang dianggap cukup sederhana tetapi tidak selalu mudah dilakukan, terutama pada keluarga yang belum terbiasa. Salah satu studi Badan Kesehatan Dunia (WHO) menyatakan praktik cuci tangan menggunakan sabun dan air bersih pada lima waktu tertentu, yaitu sebelum makan, setelah buang air besar, sebelum memegang bayi, setelah menceboki pantat anak, dan sebelum menyiapkan makanan bisa mengurangi prevalensi diare sampai $40 \%$.

$$
\text { ncuci tangan diterapkan }
$$
setelah buang air besar, setelah menceboki bayi dan balita, sebelum makan serta sebelum menyiapkan makanan. Masyarakat akan mampu meningkatkan pengetahuan hidup sehat dimanapun mereka berada jika mereka sadar, termotivasi dan di dukungan dengan adanya informasi serta saranadan prasarana kesehatan. Masyarakat hanya mengetahui penyakit menular pada penyakit tertentu saja sedangkan untuk penyakit dalam atau penyakit infeksilainya masih kurang sehingga kesadaran untuk masyarakat dalam menjaga hidup sehat, dan menjaga dirinya dari bahaya penyakit menular terbatas pada apa yang mereka ketahui saja. Mencuci tangan merupakan 
metode tertua, sederhana dan paling konsisten untuk pencegahan dan pengontrolan penularan infeksi (Perry \& Potter 2005). Maka dari sebagai ibu diharus kan untuk mencuci tangan sebelum mengolah atau memasak suatu makanan untuk keluarga tercintanya agar terhindar dari penyakit.Menurut penelitian WHO, 100 ribu anak Indonesia meninggalsetiap tahunnya karena diare. Data yang dirilis oleh Riskedas tahun 2007 menyebutkan diare termasuk salah satu dari dua penyebab kematian terbanyak pada anak-anak, selain pneumonia. Kematian pada pada anak umur 4-11 tahun yang disebabkan diare sebanyak $25,5 \%$ dan pneumonia15,5\%. Sebanyak 40 hingga $60 \%$ diare pada anak terjadi akibat rotavirus. Biasanya virus masuk mulut melalui tangan yang terkontaminasi kotoran akibat tidak mencuci tangan.

\footnotetext{
Keberadaan hand sanitizer sangat membantu menjaga kebersihan tangan di masa pandemi Covid-19. Menjaga kebersihan tangan merupakan salah satu anjuran yang digaungkan oleh Organisasi
}

Kesehatan Dunia (WHO) untuk menekan penyebaran Covid-19. Kebersihan tangan bisa dijaga melalui rajin mencuci tangan dengan air dan sabun. Hand sanitizer bisa digunakan sebagai alternatif bila tidak ada air dan sabun. Hal ini mendorong terjadinya peningkatan penggunaan hand sanitizer di masa pandemi. Studi yang melibatkan 434 tenaga kesehatan menunjukkan bahwa 74 persen partisipan menggunakan hand sanitizer lebih dari 10 kali per hari.

Salah satu cara paling umum yang dilakukan untuk membersihkan tangan yaitu dengan menggunakan sabun namun seiring bertambahnya kesibukan manusia menyebabkan meningkatnya kebutuhan produkproduk praktis yaitu pembersih tangan tanpa air atau yang sering disebut hand sanitizer. Pemakaian antiseptik tangan saat ini mendapatkan respon yang cukup positif dari masyarakat mengingat semakin banyaknya merk antiseptik dipasaran. Menurut penelitian Desiyanto, dkk (2013) perlakuan cuci tangan dengan hand sanitizer efektif dalam penurunan jumlah 
angka kuman. Bahan antiseptik yang sering digunakan dalam formula sediaan adalah dari golongan alkohol (etanol, propanol, isopropanol) dengan konsentrasi $\pm 50 \%$ sampai $70 \%$ dan jenis disinfektan yang lain seperti : klorheksidin, triklosan. Namun dalam penggunan alkohol sebagai antiseptik memiliki beberapa kekurangan yaitu alkohol mudah terbakar dan pada pemakaian berulang menyebabkan kekeringan dan iritasi pada kulit (Sari dan Isadiartuti, 2006) disamping itu perlu pengawasan ekstra dari orang dewasa saat diberikan pada anakanak.

Mengingat beberapa kerugian dari penggunaan antiseptik tangan dari golongan alkohol tersebut keinginan untuk mendapatkan manfaat yang besar dengan efek samping minimalpun meningkat salah satunya dengan memanfaatkan bahan alam sebagai antiseptik tangan. Lidah buaya merupakan salah satu tanaman yang diketahui berkhasiat sebagai antiseptik. Aloe vera. var sinensis adalah salah satu tanaman yang banyak dijumpai di Indonesia baik dilingkungan rumah maupun lingkungan luar yang banyak dimanfaatkan sebagai tanaman hias. Selain penanaman yang mudah tanaman ini memiliki banyak manfaat dalam pengobatan. Diketahui bahwa lidah buaya (Aloe vera) telah lama digunakan dalam pengobatan tradisioal. Menurut Kusumawati et all (2012) lidah buaya mempunyai aktivitas antijamur, antivirus dan antibakteri aktivitas antibakterinya ditunjukkan oleh kandungan kompleks antrakuinon. Penelitian perbandingan lidah buaya terhadap beberapa standart antibiotik (metisilin, basitrasin, novobiosin, dan eritromisin) menunjukkan bahwa gel lidah buaya efektif terhadap bakteri Gram positif sebesar $75,3 \%$ dari bakteri yang diisolasi meliputi Staphylococcus aureus, Staphylococcus epidermidis, Streptococcus pyogenes dan bakteri Gram negatif sebesar 100\% dari bakteri yang diisolasi meliputi Pseudomonas aeruginosa, sedangkan daun lidah buaya tidak efektif terhadap keseluruhan Gram negatif maupun Gram positif. 


\section{Landasan Teori}

II.I Konsep Hand Hygiene

II.II Definisi Hand Hygiene

Menurut Ernawati (2014:1)

hand hygiene merupakan sebuah istilah dari mencuci tangan menggunakan antiseptic cuci tangan. Nurjannah (2015:1) berpendapat hand hygiene adalah suatu tindakan yang dilakukan oleh perawat untuk mencuci tangan pada situasi meliputi sebelum menyentuh pasien, sebelum melakukan prosedur bersih/aseptik, setelah kontak dengan cairan tubuh pasien, setelah menyentuh pasien, dan setelah menyentuh peralatan di sekitar pasien sebagai salah satu cara untuk mengurangi atau mencegah infeksi nosokomial. Sementara itu menurut Tietjen (2004, dalam Rismawati 2013:9) mengatakan proses pembuangan kotoran dan debu secara mekanis dari kulit tangan dengan memakai air dan sabun. Sedangkan menurut Perdalin (2010, dalam Saragih \& Rumapea, 2011:5) menjelaskan bahwa hand hygiene merupakan suatu prosedur tindakan membersihkan tangan dengan menggunakan sabun/antiseptik dibawah air mengalir atau dengan menggunakan handrub yang bertujuan untuk menghilangkan kotoran dari kulit secara mekanis dan mengurangi jumlah mikroorganisme sementara.

\section{II.III Indikasi Cuci Tangan}

Dalam WHO (2010:19) disepakati bahwa sistem CDC / HICPAC untuk rekomendasi kategorisasi menjadi diadaptasikan sebagai berikut:

1. Kategori 1A. Sangat disarankan untuk implementasi dan sangat didukung oleh studi eksperimental, klinis, dan epidemiologi dirancang dengan baik (WHO, 2010 : 16).

2. Kategori 1B. Sangat disarankan untuk implementasi dan didukung oleh beberapa studi eksperimental, klinis, dan epidemiologi dan pemikiran teoritis yang kuat (WHO, 2010 :16).

3. Kategori 1C. Diperlukan untuk implementasi, sebagaimana diamanatkan oleh federasi dan atau negara degan peraturan standar (WHO, 2010 : 16). 
4. Kategori II. Disarankan untuk implementasi dan didukung oleh studi klinis dan epidemiologis yang disarankan atau dasar pemikiran teoritis atau konsensus oleh ahli (WHO, 2010 : 16).

Menurut WHO (2010) ada beberapa indikasi yang di rekomendasikannya diantaranya adalah :

1. Cuci tangan dengan sabun dan air bila jelas terlihat kotor atau terkontaminasi dengan bahan protein, atau terlihat kotor dengan darah atau cairan tubuh lainnya, atau jika paparan potensi organisme membentuk spora sangat dicurigai atau terbukti (IB) atau setelah menggunakan kamar kecil.(II).

2. Sebaiknya menggunakan antiseptik berbasis alkohol untuk antisepsis tangan rutin di semua situasi klinis lain yang dijelaskan dalam item $\mathrm{Ca}$ untuk CF di bawah ini jika tangan tidak tampak kotor (IA). Atau, mencuci tangan dengan sabun dan air (IB).
3. Melakukan kebersihan tangan:

1) Sebelum dan setelah kontak langsung dengan pasien (IB).

2) Setelah melepas sarung tangan (IB).

3) Sebelum menangani tindakan invasif (terlepas dari apakah atau tidak sarung tangan yang digunakan) untuk perawatan pasien (IB).

4) Setelah kontak dengan cairan tubuh atau sekret, membran mukosa, kulit yang tidak utuh, atau pembalut luka (IA).

5) Jika menyentuh dari tempat tubuh yang terkontaminasi ke tempat tubuh yang bersih selama perawatan pasien (IB).

6) Setelah kontak dengan benda mati (termasuk peralatan medis) di daerah sekitar dari pasien (IB).

4. Cuci tangan yang baik memakai sabun antimikroba dan air atau menggosok tangan dengan handrub 
sebelum memberi obat-obatan dan menyiapkan makanan (IB).

5. Ketika sudah menggunakan handrub, jangan gunakan sabun antimikroba bersamaan (II).

Selain itu menurut ditambahkan lagi WHO dalam Maryanti (2016) dijelaskan bahwa indikasi hand hygiene sebagai berikut :

1. Mencuci tangan dengan sabun dan air ketika terlihat kotor atau terpapar darah atau cairan tubuh lain atau setelah menggunakan toilet.

2. Jika terbukti terpapar pada potensial pathogen, termasuk infeksi oleh Costridium difficile, mencuci tangan dengan sabun dan air terbukti lebih ampuh.

3. Menggunakan cairan antiseptik (handrub) secara rutin untuk antiseptik tangan. Apabila tidak terdapat cairan antiseptik, cuci tanganlah menggunakan air dan sabun.

4. Pelaksanaan five moments

1) Sebelum menyentuh pasien
2) Sebelum prosedur membersihkan/aseptik

3) Setelah terpapar cairan

4) Setelah menyentuh pasien

5) Setelah menyentuh lingkungan pasien

6. Setelah melepas sarung tangan steril maupun non-steril.

7. Sebelum menyiapkan obat dan makanan

8. Sabun dan cairan antiseptik (alcohol-based) hand rub tidak boleh dilakukan

5. bersama-sama

Menurut Depkes RI (1993, dalam Syamsidi 2013) indikasi cuci tangan adalah:

1. Sebelum melakukan prosedur infasif misalnya : menyuntik, pemasangan keteter dan pemasangan alat bantu pernapasan

2. Sebelum melakukan asuhan keperawatan langsung

3. Sebelum dan sesudah merawat setiap jenis luka

4. Sebelum tindakan tertentu, tangan diduga tercemar dengan microorganisme kususnya pada tindakan yang memungkinkan 
kontak dengan darah, selaput lendir, cairan tubuh, sekresi atau eksresi

5. Setelah menyentuh benda yang kemungkinan terkontaminasi dengan mikroorganisme

6. Setelah melakukan asuhan keperawatan langsung ada pasien yang terinfeksi atau kemungkinan kolonisasi mikroorganisme yang bermakna secara klinis atau epidemiologi.

7. Setiap kontak dengan pasienpasien di unit resiko tinggi, setelah melakukan asuhan langsung maupun tidak langsung pada pasien yang tidak infeksius.

III.IV Keuntungan Cuci Tangan WHO (2010:26) mengatakan cuci tangan dapat memberikan keuntungan sebagai berikut:

1. Dapat menurunkan tingkat resiko infeksi.

2. Mencegah terjadinya pasien terkena infeksi nosokomial.

3. Mengurangi penyebaran organisme multiresisten pada saat melakukan tindakan keperawatan.

4. Dari segi praktis dan hemat biaya, cuci tangan juga dapat menurukan terjadinya pembengkakan biaya yang terjadi jika pasien terkena infeksi akibat kurangnya hand hygiene

Menurut Syamsidi (2013) keuntungan cuci tangan yaitu :

1. Dapat mengurangi infeksi nosokomial.

2. Jumlah kuman yang terbasmi lebih banyak sehingga tangan lebih bersih dibandingkan dengan tidak mencuci tangan.

3. Dari segi praktis, ternyata cuci tangan lebih murah daripada tidak mencuci tangan sehingga pada akhirnya, dapat menyebabkan infeksi nosokomial.

II.V Macam-Macam Cuci Tangan Menurut WHO (2013:14-15) bahwa hand hygiene atau yang sering disebut dengan cuci tangan, di dalam dunia kesehatan dibedakan menjadi tiga tipe yaitu cuci tangan 
medical (medical hand washing), cuci tangan surgical (surgical hand washing), dan cuci tangan operasi (operatting theatre hand washing). Tata cara atau prinsip hand hygiene yang efektif rekomendasi WHO (2009:2-3) dengan sabun (handwash) atau dengan alkohol (handrub) semua menggunakan 6 langkah akan tetapi yang membedakan waktu atau durasi pelaksanaannya yaitu handwash memerlukan waktu 40-60 detik, sedangkan handrub memerlukan waktu 20-30 detik. Berikut adalah langkah handwash dan handrub.

Menurut Maryanti \& Dewi (2016) macam-macam hand hygiene sebagai berikut:

1. Alcohol-based hand rub

Bahan yang mengandung alkohol yang dapat berupa cairan, gel, atau buih yang dirancang untuk tangan dapat menonaktifkan mikroorganisme dan atau menekan pertumbuhannya sementara waktu.

2. Antimicrobial (medicated) soap

Sabun atau detergen mengandung sejumlah agen antiseptic untuk menonaktifkan mikroorganisme dan atau menekan pertumbuhannya sementara waktu seperti alkohol. Aktifitas detergen seperti sabun juga dapat mengeluarkan mikroorganisme atau kontaminan yang lain dari kulit setelah itu akan dibersihkan oleh air.

3. Antiseptic agent

Agen antiseptik merupakan suatu zat antimikroba yang menonaktifkan mikroorganisme atau menghambat pertumbuhannya di jaringan hidup. Contoh agen antiseptik adalah alcohol, chlorhexidine gluconate (CHG), chlorine derivatives, iodine, chloroxylenol (PCMX), quaternaryammoniumcompounds, dan triclosan.

4. Antiseptic hand wipe

Sapu tangan antiseptik merupakan satu lembar kain tipis atau kertas yang sebelumnya di bahasahi dengan antiseptik yang digunakan untuk menyeka tangan untuk menonaktifkan dan atau menghilangkan kontaminan mikroba. Cara ini mungkin bisa dipertimbangkan sebagai alternatif untuk mencuci tangan tanpa sabun dan air, namun cara ini kurang efektif dalam mengurangi jumlah 
bakteri pada tangan tenaga kesehatan dibandingkan dengan menggunakan handrub alcohol atau mencuci tangan dengan sabun antimikroba dan air.

5. Detergent (surfactant)

Deterjen merupakan bahan campuran yang memiliki aktivitas membersihkan. Deterjen memiliki dua jenis zat yaitu hidrofilik dan lipofilik. Deterjen juga dibedakan kedalam empat kelompok yaitu anionic, cationic, amphoteric, dan non-ionic

6. Plain soap

Sabun sederhana ini tanpa ditambahi dengan zat antimikroba dan semata-mata hanya untuk membersihkan kotoran saja.

7. Waterless antiseptic agent

Agen antiseptik tanpa air ini merupakan agen antiseptic berupa cairan, gel, atau buih yang tidak membutuhkan air. Karena setelah penggunaan, individu harus menggosokan kedua tangan mereka bersamaan sampai kulit terasa kering.

Antiseptik atau pennisida adalah senyawa kimia yang digunakan untuk membunuh atau menghambat

pertumbuhan mikroorganisme pada jaringan yang hidup seperti pada permukaan kulit dan membran mukosa Antiseptik berbeda dengan antibiotik dan disinfektan, yaitu antibiotik digunakan untuk membunuh mikroorganisme di dalam tubuh, dan disinfektan digunakan untuk membunuh mikroorganisme pada benda mati. Hal ini disebabkan antiseptik lebih aman diaplikasikan pada jaringan hidup, daripada disinfektan Namun, antiseptik yang kuat dan dapat mengiritasi jaringan kemungkinan dapat dialih fungsikan menjadi disinfektan contotunya adalah fenol yang dapat digunakan baik sebagai antiseptik maupun disinfektan Penggunaan antiseptik sangat direkomendasikan ketika terjadi epidemi penyakit karena dapat memperlambat penyebaran penyakit.

Efektivitas antiseptik dalam membunuh mikroorganisme bergantung pada beberapa faktor, misalnya konsentrasi dan lama paparan Konsentrasi mempengaruhi adsorpsi atau penyerapan komponen antiseptik. Pada konsentrasi rendah, 
beberapa antiseptik menghambat fungsi biokimia membran bakteri, namun tidak akan membunuh bakteri tersebut Ketika konsentrasi antiseptik tersebut tinggi, komponen antiseptik akan berpenetrasi kedalam sel dan menganggu fungsi normal seluler secara luas, termasuk menghambat biosintesis pembuatan makromolekul dan persipitasi protein intraseluler dan asam nukleat (DNA atau RNA). Lama paparan antiseptik dengan banyaknya kerusakan pada sel mikroorganisme berbanding lurus. Mekanisme kerja antiseptik terhadap mikroorganisme berbeda-beda, misalnya dengan mendehidrasi (mengeringkan) bakteri, mengoksidasi sel bakteri, mengkoagulasi (mengumpulkan) cairan disekitar bakteri atau bakteri.

8. Hand Sanitizer

Hand Sanitizer merupakan pembersih tangan yang memiliki kemampuan antibakteri dalam menghambat hingga membunuh bakteri (Retnosari dan Isdiartuti, 2006). Menurut Diana (2012) terdapat dua hand sanitizer yaitu hand sanitizer gel dan hand sanitizer spray. Hand sanitizer gel merupakan pembersih tangan berbentuk gel yang berguna untuk membersihkan atau menghilangkan kuman pada tangan, mengandung bahan aktif alkohol $60 \%$. Hand sanitizer spray merupakan pembersih tangan berbentuk spray untuk membersihkan atau menghilangkan kuman pada tangan yang mengandung bahan aktif irgasan DP $300: 0,1 \%$ dan alkohol $60 \%$. Penelitian Diana (2012) menyatakan, hand sanitizer yang berbentuk cair atau spray lebih efektif dibandingkan hand sanitizer gel dalam menurunkan angka kuman pada tangan.

Banyak hand sanitizer yang berasal dari bahan alkohol atau etanol yang dicampurkan bersama dengan bahan pengental, misal karbomer, gliserin, dan menjadikannya serupa jelly, gel atau busa untuk mempermudah dalam penggunaannya. Gel ini mulai populer digunakan karena penggunaanya mudah dan praktis tanpa membutuhkan air dan sabun. Gel sanitasi ini menjadi alternatif yang nyaman bagi masyarakat. (Hapsari, 2015) Seiring 
perkembangan zaman, dikembangkan juga pembersih tangan non alkohol, tetapi jika tangan dalam keadaan benar - benar kotor, baik oleh tanah, udara, darah, ataupun lainya, mencuci tangan dengan air dan sabun lebih disarankan karena gel hand sanitizer tidak dapat efektif membunuh kuman dan membersihkan material organik lainnya. Alkohol banyak digunakan sebagai antiseptik /desinfektan untuk desinfeksi permukaan kulit yang bersih, tetapi tidak untuk kulit yang luka (Hapsari, 2015). Selain itu alkohol juga mempunyai sifat iritasi pada kulit, mudah terbakar, dan juga meningkatkan infeksi virus pemicu radang saluran pencernaan, karena itu muncul ide untuk memanfaatkan bahan alami yang dapat mengurangi resiko munculnya penyakit gangguan pencernaan (Cahyani, 2014).

III.VI Pelatihan membuat Hand Sanitizer

Keberadaan hand sanitizer sangat dibutuhkan di tengah pandemi virus corona. Masyarakat memburu cairan antiseptik tersebut demi menjaga kebersihan diri untuk menghindari Covid-19. Berikut bahan dan cara membuat Hand Sanitizer berstandar WHO.

Bahan :

1. 1 cangkir $99 \%$ Isopropil alkohol (alkohol gosok)

2. $1 / 2$ cangkir gel lidah buaya atau aloe vera

3. 15 tetes essential oil (seperti tea tree oil, lavender oil, atau eucalyptus oil)

4. Wadah bersih dan steril

5. Botol atau container lain

Cara membuat:

1. Pertama, siapkan wadah bersih dan steril

2. Masukan bahan isopropil alkohol ke dalam wadah yang telah disiapkan

3. Lalu, tambahkan gel lidah buaya dengan. Gunakan takaran 2:1 antara alkohol dan lidah buaya.

4. Selanjutnya tuangkan essential oil. Aduk semua bahan dengan merata.

5. Terakhir tuang semua bahan ke dalam botol atau container yang telah disiapkan.

Pastikan botol atau container yang digunakan untuk menampung 
hand sanitizer dalam kondisi bersih dan steril. Selain itu, hand sanitizer juga baru dapat digunakan setelah 72 jam pembuatan. Ini adalah tata cara yang diimbau WHO soal pembuatan hand sanitizer.

\section{Identifikasi dan Perumusan}

\section{Masalah}

Dari uraian di atas, muncul berbagai permasalahan sebagai berikut:

"Bagaimana Pelatihan Pembuatan Hand Sanitizer Berstandar WHO (World Health Organization) dalam mengantisipasi pencegahan penularan Covid-19?”.

\section{Tujuan Kegiatan}

Program "Pelatihan Pembuatan Hand Sanitizer Berstandar WHO (World Health Organization)" memiliki tujuan yaitu sebagai berikut:

i. Meningkatkan pemahaman, kesadaran dan ketertarikan kelompok sasaran di Desa Jatisari untuk mengantisipasi pencegahan penularan Covid19 dengan melalui cuci tangan dan menggunakan hand sanitizer.

ii. Meningkatkan pengetahuan kelompok sasaran di Desa Jatisari tentang pembuatan hand sanitizer berstandar WHO.

iii. Memberikan informasi penggunaan hand sanitizer untuk pencegahan penularan Covid-19.

\section{Manfaat Kegiatan}

Dengan demikian Pelatihan Pembuatan Hand Sanitizer Berstandar WHO (World Health Organization) memberikan pola hidup sehat dan bersih dengan selalu menggunakan hand sanitizer saat dalam melaksanakan kegiatan diluar rumah bagi kelompok sasaran.

\section{Kerangka Pemecahan Masalah \\ Program "Pelatihan Pembuatan Hand Sanitizer Berstandar WHO (World Health Organization)" memiliki kegiatan yaitu sebagai berikut:}

1) Sosialisasi Pentingnya Pendidikan Berkelanjutan di Era Revolusi Industri 4.0 di 
Kecamatan Jenggawah, yaitu Desa Jatisari yang akan dilaksanakan pada hari Minggu, 13 Desember 2020 Pukul 10.00 WIB - 12.00 WIB. Pelatihan di Balai Desa, Desa Jatisari dilakukan dengan metode pemaparan materi, pelatihan (praktik) dan diskusi kepada kelompok masyarakat di Desa Jatisari.

\section{VI.I Target Group}

Program

Pelatihan

Pembuatan Hand Sanitizer

Berstandar WHO (World Health Organization) ini merupakan program sosialisasi yang dilaksanakan dengan melibatkan kelompok masyarakat khusunya Kelompok Ibu Rumah Tangga Penerima PKH di Desa Jatisari, Kecamatan Jenggawah, Kabupaten Jember.

\section{VI.II Target Pencapaian}

Program $\begin{array}{r}\text { Pelatihan } \\ \text { Pembuatan Hand } \\ \text { Berstandar WHO (World }\end{array}$ Health
Organization) memiliki target
pencapaian salah satunya:

1) Target pencapaian pelatihan, adalah meningkatnya pemahaman dan ketertarikan melibatkan kelompok masyarakat terhadap pembuatan hand sanitizer dalam mengantisipasi pencegahan penularan Covid19.

2) Target pencapaian pelatihan adalah kelompok sasaran dapat membuat hand sanitizer secara mandiri setelah progam pelatihan selesai.

3) Target pencapaian pelatihan meliputi kehadiran 30 (orang) kelompok masyarakat.

\section{Khalayak Sasaran}

VII.I Pelaksanaan Pelatihan Pelaksanaan pelatihan dilaksanakan untuk meningkatkan pemahaman, kesadaran dan ketertarikan ketertarikan kelompok masyarakat terhadap pemahaman pelatihan pembuatan hand sanitizer berstandar WHO (World Health Organization), pelatihan ini menjadi faktor pendukung utama untuk kesuksesan progam pemerintah 
dalam pencegahan penularan Covid-

19 dalam masa pandemi. Pelatihan dilakukan dengan dua model yaitu temu warga dan model penyebaran pamflet.

\section{Metode Kegiatan}

Program pelatihan pembuatan hand sanitizer berstandar WHO (World Health Organization) dilaksanakan pada Minggu, 13 Desember 2019 pukul 10.00 - 12.00 WIB bertempat di Balai Desa, Jatisari, Kecamatan Jenggawah. Pendaftar pelatihan tercatat sebanyak 20 Orang dengan kehadiran 14 Orang. Dari 20 orang tersebut, ternyata tidak semuanya hadir untuk sosialisasi, karena beberapa alasan, yaitu sebagai berikut:

1. Beberapa peserta tidak bisa hadir dikarenakan sedang bekerja.

2. Beberapa peserta tidak hadir tanpa keterangan.

Pada pelaksanaan program berlangsung, peseta pelatihan yang hadir akan diberikan materi terkait sosialisasi "Pelatihan Pembuatan Hand Sanitizer Berstandar WHO (World Health Organization)". Agar kelompok masyarakat mengerti apa pentingnya dalam mencegah penularan Covid-19 dengan menggunakan hand sanitizer. Setelah peserta mengikuti pelatihan, panitia akan memberikan sejumlah materi terkait pembuatan hand sanitizer berstandar WHO.

Dari pencapaian pelaksanaan program tersebut, diharapkan kelompok masyarakat memahami arti penting pendidikan berkelanjutan. Diharapkan untuk kedepannya setelah pelaksanaan pelatihan ini, kelompok masyarakat dapat mengerti akan pentingnya pelatihan pembuatan hand sanitizer berstandar WHO (World Health Organization).

\section{Khalayak Sasaran}

Kegiatan penyuluhan ini diikuti oleh 14 Peserta pelatihan diantaranya kelompok masyarakat "Kelompok Ibu Rumah Tangga Penerima PKH”, Kecamatan Jenggawah, Kabupaten Jember dengan harapan kelompok masyarakat tersebut dapat mengerti akan pentingnya pelatihan pembuatan hand sanitizer berstandar WHO (World Health Organization). 


\section{Evaluasi Kegiatan}

estimates. Geneva: World

Evaluasi kegiatan ini

dilakukan dengan pemantauan

setelah pelaksanaan kegiatan

pelatihan ini, yaitu semakin mengerti

akan pentingnya pelatihan

pembuatan hand sanitizer berstandar

WHO (World Health Organization)

untuk mencegah dan mengantisipasi

penularan Covid-19 dimasa pandemi.

\section{Daftar Pustaka}

Kusumawati, Farad, Hartono, Y. 2012. Buku Ajar Keperawatan Jiwa. Jakarta: Salemba Medika

Maryanti, Dwi, dkk. (2011). Buku Ajar Neonatus, Bayi dan Balita. Jakarta: Trans Info Media.

Radji, Maksum. 2010. Buku Ajar Mikrobiologi Panduan Mahasiswa Farmasi danKedokteran. Jakarta: EGC.

Rismawati, Dwina, 2013. Hubungan sanitasi rumah dan personal hygiene dengan kejadian kusta multibasiler. [dikutip 20 November 2015]. Tersedia di http://journal.unnes.ac.id/sju/in dex.php/ujph.

WHO, UNICEF. Low birthweight: country, regional and global 